\title{
Jak opowiadać dziecku o Zagładzie? Opis przypadku (na podstawie twórczości Irit Amiel)
}

\author{
How to tell a child about the Holocaust ? A case study \\ based on the works of Irit Amiel
}

\author{
Marta Tomczok \\ Uniwersytet Śląski \\ IORCID: 0000-0001-9512-007X
}

\begin{abstract}
In the article, I initially analyze the issue of passing on to young children, brought up in non-Jewish families, the knowledge about the Holocaust. In this article I refer to the example of my seven-year-old daughter who, influenced by my work on the book about Irit Amiel, became interested in the Holocaust, its history and literature. Thanks to the interview, I try to understand which of the objects connected with the writer and why they influenced the seven-year-old child, and whether my own experience can be helpful in educating other young children.
\end{abstract}

Key words: child, daughter, the Holocaust, Irit Amiel, conversation, teaching

Streszczenie: $\mathrm{W}$ artykule wstępnie analizuję zagadnienie przekazywania małym dzieciom, wychowanym w rodzinach nieżydowskich, wiedzy o Zagładzie. Sięgam w tym celu po przykład siedmioletniej córki, która pod wpływem mojej pracy nad monografią twórczości ocalałej Irit Amiel, zainteresowała się Holokaustem, jego historią, oddziaływaniem na biografie pojedynczych ludzi oraz literaturę. Dzięki zebranemu wywiadowi staram się zrozumieć, które z obiektów łączących się z osobą pisarki i dlaczego oddziałały na siedmioletnie dziecko, i czy można własne doświadczenie uczynić pomocnym w edukowaniu innych małych dzieci.

Słowa kluczowe: dziecko, córka, Zagłada, Irit Amiel, rozmowa, uczenie

\section{Zarys problemu}

Zajmując się od kilkunastu lat prawie wyłącznie badaniami Zagłady, miałam wiele powodów, by zastanowić się, jak rozmawiać o tym problemie z dziećmi. Najwięcej okazji dostarczało mi i wciąż dostarcza moje własne macierzyństwo oraz wychowywanie trzech kilkuletnich córek i rocznego syna. Nic tak bardzo nie wytrąca z równowagi i naukowego odrętwienia, jak pytania stawiane przez zaciekawione dzieci, z którymi pozostaje się w bliskim kontakcie, szczególnie jeśli są to pytania podające w wątpliwość jego podstawy, trudne, takie, na które nie ma często żadnych odpowiedzi. 
Kilka miesięcy temu, pracując nad książką o twórczości Irit Amiel, wróciłam mimochodem do problemu rozumienia Zagłady przez małe dzieci. Doświadczenie związane z tym, że potomstwo interesuje się warsztatem pracy rodzica-naukowca, jest dosyć powszechne i nie ma w nim nic wyjątkowego. W przypadku małych dzieci jest to jednak zainteresowanie krótkotrwałe, polegające często na próbach zabawy przedmiotami służącymi rodzicowi do pracy, takimi jak komputer (notebook), ołówki i długopisy, notatki czy książki. Sytuacja, którą chcę opisać, jest jednak inna: siedmioletnia Róża zainteresowała się Irit Amiel tak intensywnie, że próbowała napisać o niej własną książkę, wypatrywała chwil, gdy korespondowałam z pisarką bądź jej sekretarką, chociaż najbardziej zainteresowana była filmem nakręconym podczas pobytu autorki Osmalonych w Częstochowie. Nie była to pierwsza sytuacja, gdy Róża obserwowała mnie podczas pracy. Można powiedzieć nawet, że moja intensywna praca naukowa wrosła w jej dzieciństwo na trwałe. Nigdy jednak wcześniej córka tak mocno nie zareagowała na to, co robię, nie interesowała się z leżącymi na stole książkami, nie zaglądała mi przez ramię. Intensywność jej zainteresowań sprawiła, że postanowiłam przyjrzeć im się nie tylko jako matka, ale też jako autorka wspomnianej książki i badaczka zainteresowana problemem mówienia dzieciom o ludobójstwie. Ta złożona, w zasadzie trójstopniowa pozycja (matki, badaczki i autorki), pozwoliła mi do pewnego stopnia inaczej niż do tej pory zbudować narrację; świadoma własnych uwikłań w przedmiot namysłu wybrałam więc opowieść w pierwszej osobie, opisując własne dziecko, liczę się bowiem z ograniczoną skutecznością przeprowadzonej próby. Traktuję niniejsze opracowanie $\mathrm{z}$ jednej strony jako relację autobiograficzną o pewnych cechach dyskursu naukowego, ważną być może z perspektywy czyichś badań, z drugiej - jako uzupełnienie pracy nad literaturą Amiel i jej pobudzającym działaniem. Równocześnie stawiam kilka ogólnych pytań: W jaki sposób opowiadać małemu dziecku o Zagładzie? Jakimi posługiwać się w tym celu przykładami? Czy powinny one być zmyślone, odsączone z okrucieństwa, przygotowane specjalnie dla młodego odbiorcy, czy jednak warto korzystać z dokumentów, chociaż należy je starannie dobierać, licząc się z emocjonalnością małego czytelnika?

\section{Róża, lat siedem}

Moja córka uczy się w domu, w systemie, który nazywa się edukacją domową. Jej nauka ma przebieg swobodny, podyktowany naturalnymi potrzebami i odruchami, a nie jakąś konkretną podstawą programową. Wprawdzie czyta podręczniki i wypełnia obowiązkowe ćwiczenia, ale przede wszystkim chłonie książki i spędza czas na zabawie z rodzeństwem. Razem tworzą zgraną grupę. Potrafi także pisać i liczyć. Rozumienie literatury, którą się zajmuję, nie sprawia jej trudności. Pojmuje ją oczywiście na swój sposób, na swoim własnym poziomie, zwykle czytając, co chce, 
w odosobnieniu, i nie dzieląc się wrażeniami z dorosłymi, ale - i to wydaje się ważne - podejmuje samodzielne próby zaznajamiania się z różnymi tekstami, choć najchętniej wybiera komiksy.

Najwcześniej zaczęła pytać, kim są Żydzi. Interesowało ją samo słowo, które często słyszała w domu. Później, pod wpływem wyjaśnień wymagających wprowadzenia kolejnych nowych słów, takich jak wojna, Hitler, Niemcy, prześladowanie, zamykanie, śmierć, dowiedziała się, czym była Zagłada. Kluczowe wydawało mi się, by jej przekazać, w jakim mniej więcej działa się ona czasie, że było to już dawno temu, ale wciąż o tym myślimy, pamiętamy i przeżywamy tamte zdarzenia, oraz że Zagłada dotknęła - w takim właśnie wymiarze - wyłącznie Żydów, i że to eksterminacji tej części społeczeństwa, nie żadnej innej, dotyczyły plany Hitlera. Ponieważ rozmowa, podczas której padło najwięcej wyjaśnień, odbywała się mimochodem, pod wpływem pytania córki, w czasie jazdy samochodem, zapamiętałam, że największą trudność sprawiło jej zrozumienie planu Hitlera, a dokładnie tego, co należałoby nazwać antysemityzmem. Nie umiała pojąć, jak można było „uwziąć się” na jakąś grupę osób i zaplanować jej zniszczenie. Zjawiska napiętnowania nie znała z własnego doświadczenia, a myślenie, że jedna osoba może stać się ofiarą czyichś złych planów, było jej całkowicie obce.

W Irit Amiel spodobała się jej najpierw uroda. Bez wątpienia zdjęcia uśmiechniętej starszej kobiety zrobiły na niej wrażenie. Myślę, że przejęła się także jej imieniem i nazwiskiem: dwoma krótkimi, ostrymi, dźwięcznymi, ale obcymi słowami. W moim odczuciu najważniejszą okolicznością, za sprawą której siedmiolatka znalazła upodobanie w słuchaniu i czytaniu dziewięćdziesięcioletniej pisarki, stała się jej kobiecość. Róża zaczęła szukać innych kobiet poza mamą, siostrami i babciami, prawdopodobnie związanych z pisaniem, wyrazistych, przypominających jej w pewien sposób dom i dzieciństwo (o którym przecież Amiel wiele pisze). Być może przeczuwała, patrząc na zdjęcia i oglądając film, na którym Amiel wspomina bycie dzieckiem, jej serdeczność, otwartość, energiczność i żywiołowość. Nie mogła się bać niczego, co powiedziałaby osoba obdarzona takimi cechami. Irit Amiel stała się dla mojej córki prawdopodobnie symbolem przejmującej siły i stabilnego bezpieczeństwa.

\section{Obrazy, filmy, literatura}

Należałoby się zastanowić, co rzeczywiście pobudziło Różę do fascynacji bohaterką książki pisanej przez jej mamę. Zanim przedstawię wyniki naszej rozmowy, nagranej kilka miesięcy po zakończeniu pracy nad książką, chciałabym wyjaśnić, z jakiego typu źródłami biograficznymi i kulturowymi zetknęła się Róża. Jednym z pierwszych był film dokumentalny nakręcony w 2014 roku podczas pobytu pisarki w Częstochowie. Oprócz głównej bohaterki wystąpiła w nim także córka Amiel, malarka Dita. Objęte i przytulone do siebie chodziły ulicami dawnego getta, by w końcu znaleźć się 
na ulicy Przemysłowej i wspólnie przeżyć doświadczenie Irit z 27 września 1942 roku; doświadczenie powtórnych narodzin, przerzucenia przez mur, uratowania życia i utraty rodziców. Film nie dokumentował jedynie wspomnień ocalałej. Równie ważna wydawała się tutaj obecność jej córki, zaakceptowanie przez Ditę matczynych decyzji, przyjęcie na siebie jak gdyby całej usłyszanej opowieści i jej afirmacja. Dita została przedstawiona jako osoba promienna, ale milcząca, uosobienie zgody, łagodności i oddania. Oprócz jej empatii film pokazywał także wyjątkowość związku matki i córki, nie tylko pozbawionego cech charakterystycznych dla wielu międzypokoleniowych, kobiecych relacji, utrwalonych w literaturze. Uwyraźniał także wyjątkowość samego tego związku, który dla dziecka - wychowującego się razem z siostrami i zmuszonego w pewien sposób do konkurowania z nimi - mógł okazać się najważniejszy.

Tę wyjątkowość, warto dodać, zachowują także niektóre wiersze Amiel, jak chociażby Nie zdą̇̇yłam:

Nie zdążyłam do Treblinki na czas

przyjechałam spóźniona o pięćdziesiąt lat

drzewa stały nago bo była jesień

Chciałam uciec natychmiast bo jak

rekwizyt stał tam rdzewiejący pociąg

i cicho szumiał las.

Było pięknie szaro spokojnie pusto

i tylko wiatr muskał ziemię drzewa

kamienie i nas

gasząc naszą świeczkę

raz po raz

A Dita powiedziała - widzisz dobrze że nie zdążyłaś

I teraz jesteś moją starą mamą i objęła mnie mocno

I zaśmiała się smutno

(Amiel 2016, 16)

W reportażu filmowym pojawia się od czasu do czasu mała dziewczynka. Jest bohaterką tła, aktorką, prawdopodobnie mającą przypominać Irit Amiel z lat 40. W ręce trzyma tom wspomnień pisarki Życie - tytuł tymczasowy, którego publikacja stała się okazją do przyjazdu Amiel w rodzinne strony. Obecność nastolatki mogła odegrać istotną rolę w wytwarzaniu się przywiązania Róży do postaci Amiel. Identyfikacja siedmiolatki ze starszą dziewczynką, a pośrednio i pisarką, przyczyniła się też, być może, do narodzin zainteresowania dziecka Zagładą i jej literaturą, mogła również uczynić z tej literatury miejsce rzutowania pragnień, by znaleźć się w jeszcze silniejszej relacji z matką, ale jednocześnie ją przekroczyć i poszerzyć pole fascynacji o inne osoby.

Najważniejszym źródłem zainteresowań Róży postacią Irit Amiel były jednak jej opowiadania i fragmenty wspomnień dotyczące ucieczki z getta. Czytałam je córce, parafrazowałam i rozmawiałyśmy o nich. Dla 
mnie samej otwierająca zbiór Osmaleni Kartka z pamiętnika oraz rozdział Życia... zatytułowany Drugie narodziny to najważniejsza i najbliższa część tej literatury. W swojej monografii starałam się wykazać, że jest to jej serce $^{1}$. Prawdopodobnie wiele relacji ocalałych, nawet bardzo rozbudowanych, przekraczających ramy typowego świadectwa w kierunku fikcji literackiej, ma takie serce. Jednak wyjątkowość tekstów Amiel od razu rzuca się w oczy, polega bowiem na wielowariantywnym przepracowaniu zdarzeń z jesieni 1942 roku i opowiedzeniu ich raz w pierwszej osobie liczby pojedynczej (opowiadanie), innym razem w drugiej osobie liczby pojedynczej (wspomnienia), a także w formie wiersza (Próba) (Amiel 2016, 158).

Po nieudanej przeprawie na stronę aryjską wraz z całą rodziną Amiel została odprowadzona przez ojca do umówionego punktu na terenie szpitala żydowskiego, znajdującego się wówczas na ulicy Przemysłowej w Częstochowie, i o własnych siłach przedostała się przez wąski przesmyk w murze na drugą stronę, wprost do mieszkania policjanta żydowskiego, zaprzyjaźnionego z Leonem Librowiczem, ojcem dziewczynki. Tam spędziła kilka godzin, po czym udała się wraz z jego bliską znajomą, Manią, na poszukiwanie schronienia, które ostatecznie znalazła na wsi pod Częstochową².

Dla małego dziecka zrozumienie wszystkich tych szczegółów wydaje się niemożliwe. Jednak opowiadanie Kartka z pamiętnika przedstawia je w taki sposób, że stają się one interesujące także z perspektywy siedmiolatki. Bohaterka Kartki... nosi ładne ubrania („jesienny płaszczyk, beret, szalik i zieloną wełnianą garsonkę, którą mi mama zrobiła na drutach") (Amiel 2010, 7), wymienia się z rodzicami anegdotami, jest do nich bardzo przywiązana, pozwala sobie na żarty. Wydaje się, że postawę Amiel wobec rodziców mogą chcieć naśladować także współczesne dzieci: pełen swobody styl przywiązania, oparty na wzajemnym zaufaniu, trosce i poczuciu wzajemnej odpowiedzialności powinien imponować szczególnie młodszym, jeszcze dość nieśmiało stawiającym samodzielne kroki. O wiele trudniej analizować relację, jaką młody czytelnik mógłby nawiązać z tragicznymi scenami wspomnianego opowiadania, dotyczącymi bezpośrednio rozstania bohaterki z ojcem:

Ojciec podniósł mnie, kazał wyciągnąć ręce jak do pływania i wsunąć je razem z głową w tę dziurę, ale była za wąska, i trzeba było szybko zdjąć płaszczyk i znów wsunąć głowę i ręce.

Byłam zupełnie oszołomiona. Nie zdążyłam się z nim pożegnać. Pamiętam tylko, że był bardzo blady, a po twarzy błądziło mu coś między uśmiechem a płaczem.

Z drugiej strony chwycił mnie i postawił na nogi obcy wąsaty mężczyzna. Zanim zdążyłam się zorientować, mój żółty jesienny płaszczyk upadł na podłogę, a gdy podniosłam głowę, nie było już żadnej dziury. Na ścianie wisiał sobie spokojnie pozłacany obraz czarnej Matki Boskiej Częstochowskiej (Amiel 2010, 9).

\footnotetext{
${ }^{1}$ Książka ukaże się w Wydawnictwie Uniwersytetu Łódzkiego pod tytułem Amiel: $\dot{z} y c i e$ w 2021 roku.

${ }^{2}$ Dyskusję wokół tego wyjazdu i argumenty za pobytem Amiel nie pod Treblinką, jak o tym pisze we wspomnieniach, ale znacznie bliżej rodzinnego miasta, na wsi u chłopów, przeprowadzam w zapowiadanej książce.
} 
Kilkuletnie dziecko nie jest w stanie wyobrazić sobie bezpowrotnego pożegnania $\mathrm{z}$ rodzicami $\mathrm{w}$ żadnym wymiarze, nie tylko ostatecznym. Czytanie mu tego opowiadania powinno zostać poprzedzone jakimś wstępem czy wyjaśnieniem, że sytuacje rozstania przytrafiały się w czasie wojny wielu ludziom, nie tylko żydowskim dzieciom, i nie zawsze prowadziły do dramatów; ludzie bowiem odnajdywali się po wojnie, istniały możliwości wzajemnego poszukiwania się, nieraz trwającego całe lata. Zrozumienie przez dziecko, czym jest w ogóle rozłąka, jakie mogły być emocje dziewczynki błąkającej się bez rodziców ulicami groźnego miasta, gdzie panował nie tylko niemiecki terror, ale też polski antysemityzm, wydaje się przerastać jeszcze możliwości emocjonalne kilkulatka, dlatego atmosferę opowiadania należy budować i odtwarzać ostrożnie.

Najmniej interesowały Różę wiersze, choć wydawałoby się, że to one są najbardziej zrozumiałymi komunikatami w tej twórczości. Niektórzy historycy literatury, jak Piotr Mitzner, łączą ich, pozorną przecież, prostotę ze zjawiskiem nazywanym „biednym językiem” (Mitzner 2011), ogołoconym z retoryki, w przeciwieństwie do postawangardowych metafor nawiązujących dialog z odbiorcą „na poziomie oczu” (Patalas 2018, 211, 216). Mimo że moja córka zna poezję z naszych wspólnych lektur, woli opowieść, szczególnie taką, której towarzyszą obrazy. Poezja może wydawać się jej zbyt abstrakcyjna, co uzmysławia, że opowieść skierowana do kilkuletniego dziecka powinna zawierać nie tylko wiele szczegółów, ale też biograficzny background, z którym dziecko potrafiłoby się związać. Sądzę, że pewien dystans wobec wierszy może zostać skrócony, o ile tylko wyjaśni się słuchaczowi, dlaczego opowieść ma taką właśnie formę i że tu również odzywa się ten sam głos, który tak spodobał mu się na filmie.

\section{Mama Róży, Marta, lat czterdzieści jeden}

Swoją perspektywę opiszę jak najkrócej, starając się pokazać w niej jedynie to, co najbardziej potrzebne w zrozumieniu pojmowania przez Różę Zagłady w twórczości Irit Amiel. Nie wspomagałam go ani dłuższym wykładem, ani książkami, najważniejsza wydawała mi się w tej sytuacji jedynie krótka, sytuacyjna rozmowa. Podobnie jak Annette Wieviorka uważam, że rozmowa z dzieckiem o Auschwitz opiera się na podobnym zestawie pytań, co rozmowy dorosłych, a także, że „nie różnią się one [rozmowa z dzieckiem od rozmów dorosłych - M.T.] od pytań, które sama zadaję sobie w nieskończoność i które od ponad półwiecza powracają w rozważaniach historyków i filozofów" (Wieviorka 2015, 9). Wiele kwestii, o jakie pytała córka, pozostawiałam bez odpowiedzi lub formułowałam je ogólnikowo. Podobnie postępowała w rozmowie z trzynastoletnią córką francuska historyczka; zapis jej rozmów z Mathilde można traktować jako wyraz bezsilności wobec zbrodni ludobójstwa, którą mimo to próbuje się wytłumaczyć. Spotkanie tych dwu emocji, bezsilności i woli jej pokonania, widać przede wszystkim w formie rozmów opublikowanych pod tytułem Czym było Auschwitz? 
Jest ona prosta, w pewnym stopniu bezosobowa i przede wszystkim pozbawiona emocji, których należałoby się spodziewać podczas takiego dialogu. Stawiane przez trzynastolatkę pytania są zdawkowe, ale konkretne, można nawet powiedzieć: bezpardonowe ${ }^{3}$. W przypadku rozmów Róży ze mną było na odwrót: to ja stawiałam pytania, a ona odpowiadała. W ten sposób próbowałam się zorientować, co w niej zostało z lektur, co osiadło, czym naprawdę była zainteresowana, jak „przechowuje” w sobie wiedzę historyczną.

Odkąd pamiętam, nie broniłam jej dostępu do takiej wiedzy. Przygotowując się do zajęć ze studentami, wymagających zapoznania się z filmem, pozwalałam jej w tym uczestniczyć. Sceny naruszające ówczesną emocjonalność Róży bądź jej wrażliwość albo wyjaśniałam (jak podczas oglądania Naganiacza w reżyserii Ewy i Czesława Petelskich czy Miejsca urodzenia Pawła Łozińskiego), albo po prostu zatrzymywałam, jednak nigdy nie starałam się wybierać dla Róży specjalnych lektur, mających pomóc jej zrozumieć Holokaust. Podobały się jej niektóre współczesne beletryzacje biografii Janusza Korczaka, z zaciekawieniem przysłuchiwała się opowieści Mama zawsze wraca Agaty Tuszyńskiej, ale nigdy nie wykazywała tak żarliwego zainteresowania tekstem, jak w przypadku tekstów Amiel. Dodać warto, że gdy brakowało mi sił, by skończyć książkę, Róża zaproponowała, że skończy ją za mnie.

\section{Rozmowa}

Poniżej zamieszczam zapis fragmentów rozmowy z Różą, prowadzonej w styczniu 2021 roku:

M: Różyczko, co to jest zagłada Żydów?

R: Zagłada Żydów to jest takie (...), że Niemcy zabijają Żydów i zamykają w takich jakby miastach, ale takich, które otaczają mur.

M: Są otoczone murem. Pamiętasz, jak nazywały się te miasta?

R: Getto.

M: A gdzie usłyszałaś o zagładzie Żydów i gettach?

$\mathrm{R}$ : Jak rozmawiasz z tatą.

M: Przypominasz sobie pisarkę, o której kilka miesięcy temu pisałam, Irit Amiel?

R: Tak.

M: Co Cię w niej zainteresowało?

R: Nie wiem, po prostu mi się spodobała.

M: A co o niej zapamiętałaś?

R: Była przerzucona przez mur, który otaczał te miasta. A potem miała nową mamę i nowego tatę.

M: Pamiętasz może, gdzie znajdował się ten mur? W jakim mieście?

R: Nie.

M: W jakim wieku była Irit, gdy została przerzucona przez mur?

R: Była mała.

M: A to przerzucenie oznaczało dla niej zupełne pożegnanie z rodzicami?

${ }^{3}$ Oto kilka z nich: „Czy to bolało?”, „Dlaczego?”, „Bez dzieci?”, „Czym dokładnie było getto?”, cyt. za: Wieviorka A., 2015, Czym było Auschwitz. Rozmowy z moja córka, Tarasewicz P. (przeł.), Gdańsk, s. $16,23,45$. 
R: Tak.

M: A to, co pisze Amiel, jest smutne?

R: Jest trochę smutne i trochę wesołe.

M: Co masz na myśli?

R: Jeszcze nie wiem, nawet nie czytałaś mi o tym książki.

M: Co to znaczy, że Amiel jest Żydówką?

R: To znaczy, że urodziła się jako Żyd, a nie jako Polak czy ktoś inny.

\section{Wnioski}

Jak pisała Maria Montessori: „[j]eżeli więc któregoś dnia okazuje się, że dziecko jest niezwykle pracowite, że może przykładać się do pracy ze skupieniem, może kształcić się, ma w sobie naturalną dyscyplinę, jest to traktowane jak bajka, nie budzi to zdziwienia, a jedynie skojarzenia z czymś absurdalnym" (Montessori 2019, 62). Najważniejsze wydaje się pozbycie uprzedzeń i wsłuchanie się $\mathrm{w}$ naturalne potrzeby dziecka, które mogą manifestować się na różne sposoby. W przypadku mojej córki, jak sądzę, dało się zauważyć pewien kryzys, związany ze zmianą oczekiwań wobec matki i domowego otoczenia, poszerzeniem środowiska znajomych i zmianą wzorca kobiecości. Dotknął on także naszych wspólnych relacji: być może Róża była już tak zmęczona moją pracą i moim własnym zmęczeniem, że postanowiła mnie odciążyć, przejmując część moich własnych zainteresowań, w tym tych najtrudniejszych, związanych z Zagładą. Równocześnie pogłębiła swoją wiedzę na jej temat, co wydaje się tym ważniejsze, że jej chęć, by tak zrobić, okazała się autentyczna, niewymuszona i naturalna.

Impuls, by zainteresować się literaturą, pojawia się u dziecka niespodziewanie, ale wychodzi zwykle od otoczenia. Obserwując, czym się ono zajmuje, co robi, jak odnosi się do rzeczywistości i jak ją formuje, dziecko powtarza to, co widzi, i na tej podstawie kształtuje swoje umiejętności. Podpatrywanie wydaje się ważne, choć nigdy dokładnie nie wiadomo, dokąd ono dziecko zaprowadzi. Mimo iż opowiadanie sześciolatce czy siedmiolatce o Zagładzie za pomocą tzw. tekstów dla dorosłych może się dziś wydawać właśnie absurdalne, zastanawiać musi, dlaczego dzieci sięgają akurat po te właśnie teksty, a obojętnieją na literaturę tworzoną wprost dla nich, fikcyjną i w pewnym sensie „sztucznie” dostosowaną do ich wrażliwości ${ }^{4}$. W liście z grudnia 2019 roku Irit Amiel pytała: „jak można dalej nieść pamięć o tym, co się stało Żydom w Europie?”5. Sądzę, że jedynie w ten sposób, by chciały ją od nas przejąć dzieci. Literatura autorki Podwójnego krajobrazu stanowi doskonałe medium, potrafi pośredniczyć między dramatem ludzkiego losu a ujmująco zwięzłą narracją; stwarza portrety i sylwetki, o których niemożna zapomnieć. Działa jak nagłe uderzenie światła w ciemnym pokoju - po chwili staje się po prostu nieodzowna i oczywista.

\footnotetext{
${ }^{4}$ Pisałam o tym więcej: Tomczok M., 2020, Getto łódzkie we współczesnej literaturze dla dzieci i młodziė̇y. Krytyka „nowej wrażliwości”, „Zagłada Żydów. Studia i Materiały”, nr 16, s. 665-684.

${ }^{5}$ List w archiwum prywatnym autorki.
} 


\section{Bibliografia:}

Amiel Irit, 2010, Kartka z pamiętnika, w: Osmaleni, Głowiński M. (posł.), Warszawa.

Amiel Irit, 2016, Nie zdą̇̇yłam, w: Spóźniona / Delayed, Kazmierski M. (przeł.), Frymorgen B. (przedm.), Kraków - Budapeszt.

Mitzner Piotr, 2011, Biedny język. Szkice o kryzysie słowa i literaturze wojennej, Warszawa.

Montessori Maria, 2019, O kształtowaniu się człowieka, Krolczuk-Wyganowska L. (przeł.), Camarda S. (red. nauk.), Warszawa.

Patalas Agata, 2018, Proza Irit Amiel wobec „sublokatorstwa” jako kategorii kulturowej („osmaleni” wobec „sublokatorek" i „sublokatorów”), w: Historia najnowsza w literaturze i kulturze a edukacja polonistyczna, Janus-Sitarz A., Kania A. (red.), Kraków, s. 199-216.

Wieviorka Annette, 2015, Czym było Auschwitz. Rozmowy z moja córka, Tarasewicz P. (przeł.), Gdańsk.

\section{O Autorce:}

Marta Tomczok - pracuje jako profesor uczelni w Uniwersytecie Śląskim, zajmuje się literaturą Zagłady oraz krytyką literacką, interesuje się także studiami nad energią, paliwami kopalnymi, przemysłem i jego rolą kulturotwórczą. Ostatnio opublikowała monografię Czy Polacy i Żydzi nienawidza się nawzajem? Literatura jako mediacja (Łódź 2019). Niebawem ukaże się jej książka poświęcona biografii i twórczości Irit Amiel. Redaktor naczelna „Narracji o Zagładzie”. 
